Volume 5 No. 2, September 2017

P-ISSN: 2337-9251, E-ISSN: 2597-9094

Open Access at : http://jurnal.umt.ac.id/index.php/replik/index

\title{
CHECK AND BALANCES KEKUASAAN LEMBAGA NEGARA GUNA MENATA PEMERINTAHAN YANG BAIK (GOOD GOVERNMENT)
}

\author{
Sulardi \& Irmayadi Sastra \\ Fakultas Hukum Universitas Muhammadiyah Malang \\ Email : sulardi.mgl@gmail.com
}

\begin{abstract}
Abstrak
Perubahan UUD 1945 adalah merupakan awal dari pencarian sebuah solusi demi mewujudkan kesetabilan dan kesempurnaan dalam sistem pemerintahan Indonesia. Oleh karena itu dengan adanya sistem chek and balances ini diharapkan dapat memberikan sebuah regulasi baru sehingga dalam menjalankan roda pemerintah tidak tumpang tindih antara eksekutif dengan legislatif. Dengan demikian, check and balances adalah sebagai solusi terahir yang ditawarkan guna menciptakan sistem pemerintahn yang baik (good government). Namun hakikatnya yang terjadi hari ini check and balances tersebut juga belum mampu mengatasi dan menyempurkan keseimbangan antara kekuasaan eksekutif dan legisltaif. Adapun landasan keseimbangan kekuasaan lembaga negara telah dituangkan dalam UUD 1945 setelah amandemen. Namun kemudian, kebjikan ini belum berjalan secara maksimal dan efiktif karena dalam peranan masing-masing lembaga memiliki kekuasaan yang berbeda sehingga selalu ada pengaruh yang terjadi dalm sistem pemerintah di Indonesia yang dilakukan oleh lembaga Eksekutif dan Legislatif yakni Presiden dan DPR.
\end{abstract}

Kata Kunci: Kekuasaan, chek and balances, Presiden dan DPR.

\begin{abstract}
Abstrac
The amendment of the 1945 Constitution is the beginning of the search for a solution to realize stability and perfection in the Indonesian system of government.
\end{abstract}


Therefore, the existence of the system of chek and balances is expected to provide a new regulation so that in running the government does not overlap between the executive and the legislature. Thus, check and balances are the last solution offered to create a good government system. Yet the reality of today's check and balances has not been able to overcome and to strike a balance between executive and legislative power. The basis of the balance of power of state institutions has been poured in the 1945 Constitution after the amendment. But then, this praise has not run optimally and effectively because in the role of each institution has different powers so that there is always influence that occurs in the system of government in Indonesia conducted by the Executive and Legislative institutions ie the President and the House of Representatives.

Keywords: Power, check and balances, President and House of Representatives.

\section{PENDAHULUAN}

Undang-Undang Dasar Negara Republik Indonesia Tahun 1945 adalah sebagai Konstitusi Negara Indonesia. UUD 1945 merupakan sumber dari segala sumber hukum yang mangatur tatanan (konstelasi) kehidupan masyarakat maupun kehidupan ketatanegaran Indonesia. Dalam perjalanan panjang tata negara Indonesia telah membawa perubahan yang sangat kompleks dari masa kemasa, mengalami perubahan yang signifikan khususnya dalam perubahan kedaulatan kekuasaan pada lembagalembaga negara.

Amandemen UUD 1945 sudah dilakukan sebanyak empat kali perubahan pada era reformasi demi menemukan titik kesempurnaan untuk menyeimbangkan (check and balances) kekuasaan negara. Namun perubahan konstitusi tersebut juga belum memberikan konsep yang matang terhadap jalannya sistem pemerintahan dalam rangka megelola rumah tangga pemerintahan yang baik. Justru perubahan konstitusi ini tidak jelas arahnya kemana, apakah konstitusi ini dibentuk hanya sebagai semboyan belaka atau hanya sebagai simbol bahwa Indonesia memiliki kedaulatan hukum agar diakui oleh negara lain. Tetapi, dalam implementasinya tidak terarah bagaikan buih yang terombang-ambing ditengah lautan. 
Mari kita menelisik kebelakang, Dalam sejarah ketatanegaraan Indonesia UUD 1945 sudah mengalami perubahan yaitu sudah sebanyak 4 tahap. Periode perubahan tersebut yakni pada Sidang Umum MPR Tanggal 19 Oktober 1999, Sidang Tahunan MPR Tanggal 18 Agustus 2000, Sidang Tahunan MPR Tanggal 10 November 2001 dan Sidang Tahunan MPR Tanggal 10 Agustus 2002. ${ }^{1}$

Perubahan terhadap Konstitusi tersebut dari amandemen pertama hingga keempat telah melahirkan Hukum Tata Negara yang baru, yakni adanya LembagaLembaga Negara yang baru bernama Dewan Perwakilan Daerah (DPD), Komisi Yudisial (KY) dan Mahkamah Konstitusi (MK), serta Dewan Pertimbangan Agung dihapus (DPA). Selain adanya Lembaga-Lembaga Negara baru yang dilahirkan, ada juga suatu Sistem Tata Negara yang baru bernama check and balances karena dengan adanya amandemen yang memisahkan fungsi, tugas dan wewenang LembagaLembaga Negara yang ada. ${ }^{2}$

Namun, seperti yang telah dijelaskan diatas sebelumnya bahwa sistem negara tersebut tidak serta merta berjalan dengan baik dan efektif, masih saja terlihat tumpang tindih dalam menjalankan kekuasaan sehingga pelaksanaannya dilapangan sering terjadi tarik ulur kekuasaan. Sebagaimana dikatakan oleh Jaendjri Gaffar bahwa sistem check and balances atau sistem saling mengawasi dan mengimbangi antar lembaga negara ini mempersempit ruang gerak lembaga-lembaga dalam melaksanakan tugas, fungsi, hak dan kekuasaan atau wewenang untuk masuk dalam praktik penyalahgunaan kekuasaan atau "abuse of power" dan penyalahgunaan wewenang atau "detournement de pouvoir", Lord Acton mengatakan power tends to corrupt, absolute power corrupts absolutely. ${ }^{3}$

Mekanisme check and balances pada awalnya dapat dilacak dari teori pemisahan kekuasaan. Prinsip atau mekanisme ini lahir agar dalam pemisahan keuasaan tidak terjadi kebuntungan hubungan antar cabang kekuasaan serta untuk mencegah terjadinya penyalahgunaan di dalam suatu cabang kekuasaan. ${ }^{4}$

\footnotetext{
${ }^{1}$ Hezky Fernando Pitoy, 2014. Mekanisme Check And Balances Antara Presiden Dan Dpr Dalam Sistem Pemerintahan Presidensial Di Indonesia,Lex et Societatis, Vol. II/No. 5/Juni/2014, hal 28

${ }^{2}$ Ibid, hal, 29

${ }^{3}$ Janedjri M. Gaffar, "Demokrasi Konstitusional Praktik Ketatanegaraan Indonesia Setelah Perubahan UUD 1945”, Jakarta, Konstitusi Press, 2012, hlm.109.

${ }^{4}$ Ibid, hal 20
} 
Dalam ketatanegaraan Indonesia, mekanisme ini lahir ketika adanya perubahan terhadap Konstiusi 1999 hingga 2002 yang telah menganut prinsip pemisahan kekuasaan (separation of power) ${ }^{5}$ berdasarkan check and balances dan bukan lagi pembagian kekuasaan (distribution of power atau division of power). Pemisahan kekuasaan merupakan salah satu sistem yang ada dan dianut oleh berbagai negara di dunia. Teori pemisahan kekuasaan pada mulanya dikemukakan oleh dua orang ahli tata negara yakni John Locke dan Monstesquieu.

John Locke dalam bukunya Two Treaties in Civil Government (1690) memisahkan kekuasaan negara menjadi 3 (tiga) fungsi kekuasaan dari tiap-tiap negara dan ketiga kekuasaan tersebut harus dipisahkan satu dari yang lainnya yakni :

1. kekuasaan legislatif sebagai kekuasaan untuk membuat undang-undang;

2. kekuasaan eksekutif sebagai kekuasaan untuk melaksanakan undang-undang; dan

3. kekuasaan federatif sebagai kekuasaan mengadakan perserikatan dan aliansi serta segala tindakan dengan semua orang dan badan-badan di luar negeri. ${ }^{6}$

Selanjutnya, Montesquie dengan teori Trias Politica-nya dalam bukunya "L'Esprit des Lois" (1748) yaitu mengikuti jalan pikiran dari John Locke, ia membagi kekuasaan negara dalam tiga cabang meliputi :

1. kekuasaan legislatif sebagai pembuat undang-undang;

2. kekuasaan eksekutif yang melaksanakan undang-undang; dan

3. kekuasaan menghakimi atau kekuasaan yudikatif. ${ }^{7}$

Montesquieu berpendapat bahwa dalam sistem suatu pemerintahan negara, ketiga jenis kekuasaan tersebut harus terpisah, baik mengenai fungsi (tugas) maupun mengenai alat perlengkapan (organ) yang melaksanakan."8 Konstitusi telah memberikan pemisahan tugas, fungsi, hak dan kekuasaan atau wewenang masingmasing lembaga negara dalam hal ini Presiden dan DPR, serta dalam penyelenggaraanya mengimplementasikan mekanisme check and balances dalam menjakankan kewenangannya masing-masing.

Namun dalam kenyataan atau praktik ketatanegaraan seringkali sistem pemerintahan yang dianut oleh negara kita yaitu sistem presidensial seakan-akan telah

\footnotetext{
${ }^{5}$ Jimly Asshidddiqie, "Pengantar Ilmu Hukum Tata Negara Jilid II', Jakarta, Konsistusi Press, 2006, hlm. 20 .

${ }^{6}$ C.S.T. Kansil dan Christine S.T. Kansil, "Latihan Ujian Hukum Tata Negara di Indonesia", Jakarta, Sinar Grafika, 2009, hlm. 109.

${ }^{7}$ Jimly Asshidddiqie, Op. Cit., hlm. 13.

${ }^{8}$ C.S.T. Kansil dan Christine S.T. Kansil, Op. Cit., hlm. 110.
} 
bergeser pada sistem pemerintahan parlementer dan tidak lagi mencerminkan mengenai kaidah-kaidah dalam sistem pemerintahan presidensial tersebut. Dalam menjalankan kewenangannya, Presiden dan DPR dihubungkan dengan mekanisme check and balances itu sendiri, sehingga anatara Presiden dan DPR memiliki mekanisme check and balances dalam hubungan kerjanya, tetapi DPR terlihat memiliki kekuasaan yang lebih besar dan sering memasuki wilayah eksekutif. Kewenangan yang diamanatkan oleh konstitusi bisa saja disalahlgunakan oleh lembaga-lembaga negara yang ada, dalam hal ini mengenai Lembaga Presiden dan Lembaga DPR.

Konstitusi atau UUD dibentuk untuk membatasi kekuasaan yang terdapat dalam setiap negara, apabila kekuasaan tidak diberi limitasi akan menimbulkan penyalahgunaan kekuasaan dalam negara, sedangkan penyalahgunaan kekuasaan dapat berakibat terjadinya tindakan atau perbuatan sewenang-wenang. ${ }^{9}$ I Gede Panjta Astawa dan Suprin Na'a mengutip pendapat "George Jellineck yang mengatakan bahwa negara adalah organisasi kekuasaan dari sekelompok manusia yang telah berkediaman yang tertentu." Akan tetapi, walaupun sebagai organisasi kekuasaan, negara Indonesia merupakan negara yang berdasarkan hukum.

Ada begitu banyak permasalahan yang terjadi dalam kehidupan kenegaraan di Indonesia, DPR yang terlalu kuat membuat lembaga perwakilan tersebut secara tidak langsung menunjukan sistem pemerintahan yang parlementer. Perkembangan atas ketatanegaraan Indonesia yaitu atas lembaga negara dan fungsi serta wewenangnya seiring dengan perkembangan negara dan kompleksitas masyarakat yang ada. ${ }^{10}$

Oleh karena itu setiap negara selalu mengalami perkembangan dalam sistem pemerintahannya. Perkembangan ini mempengaruhi kewenangan setiap lembaga sekaligus antar lembaga yang terkait yakni Presiden dan DPR.

Ada dua hal yang dibahas dalam tulisan ini pertama mengenai pengaturan mekanisme Check and Balances antara Presiden dan DPR dalam Sistem Pemerintahan di Indonesia; Kedua tentang efektifitas penerapan mekanisme Check and Balances antara Presiden dan DPR dalam Sistem Pemerintahan Presidensial di Indonesia?

\footnotetext{
${ }^{9}$ Ellydar Chaidir, "Hukum dan Teori Konstitusi”, Yogyakarta, Kreasi Total Media Yogyakarta, 2007, hlm. 87

${ }^{10}$ Hezky Fernando Pitoy, 2014. Mekanisme Check And Balances Antara Presiden Dan Dpr Dalam Sistem Pemerintahan Presidensial Di Indonesia,Lex et Societatis, Vol. II/No. 5/Juni/2014, hal
} 


\section{PEMBAHASAN}

\section{A. Pengaturan Mekanisme Check and Balances antara Presiden dan DPR dalam Sistem Pemerintahan di Indonesia}

Indonesia adalah negara hukum (Rechtsstaat atau The Rule of Law) dan bukan negara yang berdasar atas kekuasaan belaka (Machtsstaat), hal ini terlihat dalam Pasal 1 Ayat (3) UUD 1945 yaitu "Negara Indonesia adalah Negara hukum. Oleh karena itu, hukum selalu megatur dan beperan dalam kehidupan berbangsa dan bernegara. Begitupun dengan Mekanisme check and balances Antara Presiden dan DPR. Sebagai Lembaga Negara, Presiden dan DPR diberikan kewenangan berdasarkan Konstitusi yang ada. Seperti yang dijelaskan sebelumnya, bahwa Kewenagan Presiden dan DPR diatur oleh hukum positif di Indonesia, yaitu UUD 1945 serta DPR dalam UU No. 17 Tahun 2009 Tentang MPR, DPR, DPD, dan DPRD.

Setelah amandemen UUD 1945 Pemerintah Indonesia menganut prinsip check and balances. Prinsip check and balances relatif masih baru diadopsi ke dalam sistem ketatanegaraan Indonesia, utamanya setelah amandemen UUD 1945, sehingga dalam prakteknya masih sering timbul "konflik kewenangan" antar lembaga negara ataupun dengan komisi negara yang ada.

Mekanisme check and balances merupakan salah satu tuntutan reformasi. Salah satu tujuan utama mekanisme ini adalah untuk menghindari pemusatan kekuasaan pada satu lembaga saja. Mekanisme ini cocok diterapkan di Indonesia, karena Indonesia dikenal memiliki tiga cabang kekuasaan yakni, legislatif, eksekutif dan yudikatif.

Sekalipun di Indonesia terdapat 3 cabang kekuasaan yang terlihat dalam aturannya, namun dalam praktiknya di Indonesia, system ini tidak benar-benar diterapkan secara murni, hal ini dikarenakan sistem yang dianut di Indonesia bukanlah sistem pemisahan dalam arti separation of power melainkan sistem pemisahan dalam arti formil atau disebut division of power.

Jika pemusatan kekuasaan hanya ada di tangan satu cabang kekuasaan saja, maka akan terjadi banyak gesekan negatif dan akan menimbulkan otoriterisme, serta penyalahgunaan kekuasaan dan wewenang. Sehingga dengan adanya mekanisme ini dapat mencegah ataupun meminimalisir hal-hal tersebut.

Mekanisme check and balances Presiden dan DPR terdapat dalam berbagai bidang, yaitu legislasi, anggaran, pengawasan. Dalam bidang pengawasan yakni 
terhadap jalannya pemerintahan, pemberian keputusan dan persetujuan terhadap agenda kenegaraan, pemberian pertimbangan pada agenda kenegaraan, serta dalam pengisian dan pemilihan beberapa jabatan strategis kenegaraan oleh DPR terhadap Presiden.

Mekanisme pengawasan dan perimbangan terhadap kekuasaan dan kewenangan antara Presiden dan DPR dalam bidang legislasi dan anggaran diatur dalam beberapa Pasal dalam UUD 1945, sebagai berikut :

1. Pasal 5 ayat (1) "Presiden berhak mengajukan rancangan undang-undang kepada Dewan Perwakilan Rakyat"

2. Pasal 21 ayat (2) "Jika rancangan itu, meskipun disetujui oleh DPR, tidak disahkan oleh Presiden, maka rancangan tadi tidak boleh diajukan lagi dalam persidangan Dewan Perwakilan Rakyat masa itu"

3. Pasal 22 ayat (1) "Dalam hal ihwal kegentingan yang memaksa, Presiden berhak menetapkan peraturan pemerintah sebagai pengganti undang-undang."

4. Pasal 23 ayat (2) "Rancangan undang-undang anggaran pendapatan dan belanja negara diajukan oleh Presiden untuk dibahas bersama Dewan Perwakilan Rakyat dengan memperhatikan pertimbangan Dewan Perwakilan Daerah.”

5. Pasal 23 ayat (3) "Apabila Dewan Perwakilan Rakyat tidak menyetujui rancangan anggaran pendapatan dan belanja negara yang diusulkan oleh Presiden, Pemerintah menjalankan Anggaran Pendapatan dan Belanja Negara tahun yang lalu.

Selain diatur dalam UUD 1945, check and balances di bidang legislasi dan anggaran antara Presiden dan DPR juga diatur dalam UU No. 17 Tahun 2009 Tentang MPR, DPR, DPD, dan DPRD yaitu Pasal 71 huruf : ${ }^{11}$

1. Membentuk undang-undang yang dibahas dengan Presiden untuk mendapat persetujuan bersama;

2. Memberikan persetujuan atau tidak memberikan persetujuan terhadap peraturan pemerintah pengganti undang-undang yang diajukan oleh Presiden untuk menjadi undang-undang;

3. Menerima rancangan undang-undang yang diajukan oleh DPD berkaitan dengan otonomi daerah, hubungan pusat dan daerah, pembentukan dan pemekaran serta

\footnotetext{
${ }^{11}$ Amandemen UUD 1945
} 
penggabungan daerah, pengelolaan sumber daya alam dan sumber daya ekonomi lainnya, serta yang berkaitan dengan perimbangan keuangan pusat dan daerah;

4. Membahas rancangan undang-undang sebagaimana dimaksud dalam huruf $\mathrm{c}$ bersama Presiden dan DPD sebelum diambil persetujuan bersama antara DPR dan Presiden;

5. Membahas rancangan undang-undang yang diajukan oleh Presiden atau DPR yang berkaitan dengan otonomi daerah, hubungan pusat dan daerah, pembentukan dan pemekaran serta penggabungan daerah, pengelolaan sumber daya alam dan sumber daya ekonomi lainnya, serta perimbangan keuangan pusat dan daerah, dengan mengikutsertakan DPD sebelum diambil persetujuan bersama antara DPR dan Presiden;

6. Memperhatikan pertimbangan DPD atas rancangan undang-undang tentang APBN dan rancangan undang-undang yang berkaitan dengan pajak, pendidikan, dan agama;

7. Membahas bersama Presiden dengan memperhatikan pertimbangan DPD dan memberikan persetujuan atas rancangan undang-undang tentang APBN yang diajukan oleh Presiden;

8. Melakukan pengawasan terhadap pelaksanaan undang-undang dan APBN;

9. Membahas dan menindaklanjuti hasil pengawasan yang disampaikan oleh DPD terhadap pelaksanaan undang-undang mengenai otonomi daerah, pembentukan, pemekaran, dan penggabungan daerah, hubungan pusat dan daerah, pengelolaan sumber daya alam dan sumber daya ekonomi lainnya, pelaksanaan APBN, pajak, pendidikan, dan agama;

10. Memberikan persetujuan kepada Presiden untuk menyatakan perang, membuat perdamaian dan perjanjian dengan negara lain, serta membuat perjanjian internasional lainnya yang menimbulkan akibat yang luas dan mendasar bagi kehidupan rakyat yang terkait dengan beban keuangan negara dan/atau mengharuskan perubahan atau pembentukan undang-undang;

11. Memberikan pertimbangan kepada Presiden dalam pemberian amnesti dan abolisi;

12. Memberikan pertimbangan kepada Presiden dalam hal mengangkat duta besar dan menerima penempatan duta besar negara lain;

13. Memilih anggota BPK dengan memperhatikan pertimbangan DPD; 
14. Membahas dan menindaklanjuti hasil pemeriksaan atas pengelolaan dan tanggung jawab keuangan negara yang disampaikan oleh BPK;

15. Memberikan persetujuan kepada Presiden atas pengangkatan dan pemberhentian anggota Komisi Yudisial;

16. Memberikan persetujuan calon hakim agung yang diusulkan Komisi Yudisial untuk ditetapkan sebagai hakim agung oleh Presiden;

17. Memilih 3 (tiga) orang hakim konstitusi dan mengajukannya kepada Presiden untuk diresmikan dengan keputusan Presiden;

18. Memberikan persetujuan terhadap pemindahtanganan aset negara yang menjadi kewenangannya berdasarkan ketentuan peraturan perundang-undangan dan terhadap perjanjian yang berakibat luas dan mendasar bagi kehidupan rakyat yang terkait dengan beban keuangan negara;

19. Menyerap, menghimpun, menampung, dan menindaklanjuti aspirasi masyarakat; dan

20. Melaksanakan tugas dan wewenang lain yang diatur dalam undang-undang. ${ }^{12}$

Selanjutnya, mekanisme check and balances antara Presiden dan DPR dalam bidang pengawasan, diatur dalam beberapa Pasal dalam UUD 1945, yakni :

1. Pasal 7A "Presiden dan/atau Wakil Presiden dapat diberhentikan dalam masa jabatannya oleh Majelis Permusyawaratan Rakyat atas usul Dewan Perwakilan Rakyat, baik apabila terbukti telah melakukan pelanggaran hukum berupa pengkhianatan terhadap negara, korupsi, penyuapan, tindak pidana berat lainnya, atau perbuatan tercela maupun apabila terbukti tidak lagi memenuhi syarat sebagai Presiden dan/atau Wakil Presiden.”

2. Pasal 7B ayat (1) "Usul pemberhentian Presiden dan/atau Wakil Presiden dapat diajukan oleh Dewan Perwakilan Rakyat kepada Majelis Permusyawaratan Rakyat hanya dengan terlebih dahulu mengajukan permintaan kepada Mahkamah Konstitusi untuk memeriksa, mengadili, dan memututs pendapat Dewan Perwakilan Rakyat bahwa Presiden dan/atau Wakil Presiden telah melakukan pelanggaran hukum berupa pengkhianatan terhadap negara, korupsi, penyuapan, tindak pidana berat lainnya, atau perbuatan tercela; dan/atau pendapat bahwa Presiden dan/atau Wakil Presiden tidak lagi memenuhi syarat sebagai Presiden dan/atau Wakil Presiden.”

\footnotetext{
${ }^{12}$ UU No. 17 Tahun 2009.
} 
3. Pasal 7B ayat (2) "Pendapat Dewan Perwakilan Rakyat bahwa Presiden dan/atau Wakil Presiden telah melakukan pelanggaran hukum tersebut ataupun telah tidak lagi memenuhi syarat sebagai Presiden dan/atau Wakil Presiden adalah dalam rangka pelaksanaan fungsi pengawasan Dewan Perwakilan Rakyat."

4. Pasal 7B ayat (3) "Pengajuan permintaan Dewan Perwakilan Rakyat kepada Mahkamah Konstitusi hanya dapat dilakukan dengan dukungan sekurangkurangnya 2/3 dari jumlah anggota Dewan Perwakilan Rakyat yang hadir dalam sidang paripurna yang dihadiri oleh sekurang-kurangnya $2 / 3$ dari jumlah anggota Dewan Perwakilan Rakyat."

5. Pasal 7B ayat (4) "Mahkamah Konstitusi wajib memeriksa, mengadili, dan memutus dengan seadil-adilnya terhadap pendapat Dewan Perwakilan Rakyat tersebut paling lama Sembilan puluh hari setelah permintaan Dewan Perwakilan Rakyat itu diterima oleh Mahkamah Konstitusi."

6. Pasal 7B ayat (5) "Apabila Mahkamah Konstitusi memutuskan bahwa Presiden dan/atau Wakil Presiden terbukti melakukan pelanggaran hukum berupa pengkhianatan terhadap negara, korupsi, penyuapan, tindak pidana berat lainnya, atau perbuatan tercela; dan/atau terbukti bahwa Presiden dan/atau Wakil Presiden tidak lagi memenuhi syarat sebagai Presiden dan/atau Wakil Presiden, Dewan Perwakilan Rakyat menyelenggarakan sidang paripurna untuk meneruskan usul pemberhentian Presiden dan/atau Wakil Presiden kepada Majelis Permusyawaratan Rakyat."

7. Pasal 11 ayat (1) "Presiden. dengan persetujuan Dewan Perwakilan Rakyat menyatakan perang, membuat perdamaian dan perjanjian dengan negara lain"

8. Pasal 11 ayat (2) "Presiden dalam membuat perjanjian internasional lainnya yang menimbulkan akibat yang luas dan mendasar bagi kehidupan rakyat yang terkait dengan beban keuangan negara, dan/atau mengharuskan perubahan atau pembentukan undang-undang harus dengan persetujuan Dewan Perwakilan Rakyat"

9. Pasal 13 ayat (2) "Dalam hal mengangkat duta, Presiden memperhatkan pertimbangan Dewan Perwakilan Rakyat"

10. Pasal 13 ayat (3) "Presiden menerima penempatan duta negara lain dengan memperhatikan pertimbangan Dewan Perwakilan Rakyat" 
11. Pasal 14 ayat (2) "Presiden memberi amnesti dan abolisi dengan memperhatikan pertimbangan Dewan Perwakilan Rakyat"

12. Pasal 22 ayat (1) "Dalam hal ihwal kegentingan yang memaksa, Presiden berhak menetapkan peraturan pemerintah sebagai pengganti undang-undang"

13. Pasal 22 ayat (2) "Peraturan pemerintah itu harus mendapat persetujuan Dewan Perwakilan Rakyat dalam persidangan yang berikut"

14. Pasal 24A ayat (3) "Calon hakim agung diusulkan Komisi Yudisial kepada Dewan Perwakilan Rakyat untuk mendapatkan persetujuan dan selanjutnya ditetapkan sebagai hakim agung oleh Presiden"

15. Pasal 24B ayat (3) "Anggota Komisi Yudisial diangkat dan diberhentikan oleh Presiden dengan persetujuan Dewan Perwakilan Rakyat"

16. Pasal 23F ayat (1) "Anggota Badan Pemeriksa Keuangan dipilih oleh Dewan Perwakilan Rakyat dengan memperhatikan pertimbangan Dewan Perwakilan Daerah dan diresmikan oleh Presiden"; dan

17. Pasal 24C ayat (3) "Mahkamah Konstitusi mempunyai Sembilan orang anggota hakim konstitusi yang ditetapkan oleh Presiden, yang diajukan masing-masing tiga orang oleh Mahkamah Agung, tiga orang oleh Dewan Perwakilan Rakyat, dan tiga orang oleh Presiden."

Dengan demikian, terlihat jelas bagaimana mekanisme check and balances atau mekanisme pengawasan dan perimbangan terhadap kekuasaan dan kewenangan yang erat antara Presiden dan DPR dalam Sistem Pemerintahan di Indonesia ini.

Oleh karena itu pada regulasi seperti yang telah dijelaskan diatas pada dasarnya telah memberikan aturan yang sangat jelas dalam rangka untuk menata sistem perkembangan di Indonesia. Kemudian dengan keseimbangan kekuasaan ini diharapkan mampu membawa perubahan yang baik dan efektif.

Dengan demikian, terlihat jelas bagaimana mekanisme check and balances atau mekanisme pengawasan dan perimbangan terhadap kekuasaan dan kewenangan yang erat antara Presiden dan DPR dalam Sistem Pemerintahan di Indonesia ini.

\section{B. Efektifitas Penerapan Mekanisme Check and Balances antara Presiden dan DPR dalam Sistem Pemerintahan Presidensial di Indonesia}

Jika sebelumnya ditentukan Pasal 5 ayat (1) UUD 1945 bahwa kekuasaan untuk membentuk perundang-undangan berada di tangan Presiden dan dilakukan dengan persetujuan DPR, maka dalam perubahan pertama dan kedua UUD 1945 Pasal 20 ayat 
(1) kekuasaan untuk membentuk UU itu ditegaskan berada di tangan DPR, sedangkan Presiden menurut Pasal 5 ayat (1) yang baru ditentukan hanya berhak mengajukan RUU kepada DPR. Perubahan ini menegasakan terjadinya pergeseran kekuasaan legislatif dari Presiden ke DPR, dengan konsekuensi berubalah pula pengertian kita tentang anutan prinsip pembagian kekuasaan menjadi pemisahan kekuasaan seperti dipahami selama ini. ${ }^{13}$

Check and balances merupakan prinsip pemerintahan presidensial yang paling mendasar dimana dalam negara yang menganut sistem presidensial merupakan prinsip pokok agar pemerintahan dapat berjalan dengan stabil. Didalam prinsip check and balances terdapat dua unsur yaitu unsur aturan dan unsur pihak-pihak yang berwenang. ${ }^{14}$ Untuk-unsur aturan sudah diatur dalam UUD 1945, dimana dalam unsur aturan didalam pemerintahan di Indonesia dinilai cukup baik dan namun dalam pelaksanaanya belum optimal, hal ini disebabkan karena para pihak-pihak yang tidak profesional dalam menjalankan wewenangnya. Seperti contoh, pada masa pemerintahan Presiden Susilo Bambang Yudhoyono periode pertama, partai yang mendukung adalah partai kecil, sehingga yang masuk di lembaga legislatif hanya sebagian kecil, dan sebagian besar ditempati oleh partai lain. ${ }^{15}$

Ketika Presiden mengajukan suatu kebijakan, DPR sering kali menolak kebijakan tersebut, hal itu disebabkan karena pihak DPR banyak yang tidak berpihak pada Presiden karena lebih mengutamakan kepentingan partainya dari pada profesionalisme dalam kewenangannya sebagai DPR. Hal ini menunjukan bahwa pihak - pihak yang memegang kewenanganlah yang sangat berperan dalam menentukan pemerintahan berjalan sesuai dengan prinsip check and balances atau tidak, sehingga perlu adanya pengoptimalan terhadap pelaksanaan prinsip check and balances, karena check and balances merupakan cerminan dari sistem presidensial. ${ }^{16}$

Apabila check and balances itu dapat berjalan sesuai dengan kaidah pengertiannya, maka sistem pemerintahan presidensial akan berjalan dengan stabil. Sistem check and balances itu dapat dikatakan berjalan dengan lancar yaitu apabila

\footnotetext{
${ }^{13}$ Jimly Asshidddiqie, "Hukum Tata Negara dan Pilar-Pilar Demokrasi”, Jakarta, Konsistusi Press, 2006, hlm. 20.

${ }^{14} \mathrm{http} / /$ pugara.blogspot.com/2010/06/mengoptimalkan-check-and-balances.html ditelusuri tanggal 10 Mei 2014.

${ }^{15}$ Ibid.

${ }^{16}$ Janedjri M. Gaffar, Op. Cit., hlm. 117.
} 
antar lembaga negara dapat saling mengontrol dan mengimbangi antar lembaga negara, baik eksekutif, legislatif, maupun yudikatif secara konstitutional.

Dalam sistem pemerintahan presidensial di Indonesia, untuk mengimbangi dan mengawasi kekuasaan Presiden, terdapat DPR dan DPD sebagai lembaga parlemen atau lembaga legislatif yang memiliki fungsi legislasi, anggaran dan pengawasan. Melalui fungsi legislasi, kekuasaan Presiden menjalankan pemerintahan dibatasi dan diimbangi melalui undang-undang yang dibuat bersama-sama Presiden, serta untuk beberapa bidang tertentu juga melibatkan DPD sebagai representasi daerah.

Pengimbangan terhadap kekuasaan Presiden juga terjadi dalam proses pembuatan APBN sebagai acuan dalam penyelenggaraan pemerintahan dan pembangunan sebagai bagian dari fungsi anggaran. Untuk ditetapkan sebagai APBN, setiap Rancangan APBN harus disetujui DPR, dengan masukan atau pertimbangan dari DPD. Dengan demikian, sesungguhnya DPR dan DPD juga ikut menentukan kebijakan program pemerintahan dan penganggaran yang tertuang dalam APBN. ${ }^{17}$

Selain dalam hal proses pembuatan APBN, pengimbangan kekuasaan juga terlihat ketika proses pemilihan dan pelantikan anggota BPK, dimana anggota BPK dipilih oleh DPR dengan memperhatikan pertimbangan DPD yang nantinya akan diresmikan oleh Presiden. Begitupun dalam hal pemilihan anggota Hakim Konstitusi yang ditetapkan oleh Presiden, yang diajukan masing-masing 3 orang oleh MA, DPR dan Presiden. ${ }^{18}$

Penerapan check and balances dalam sistem pemerintahan di Indoensia oleh Presiden dan DPR, seringkali tidak sesuai lagi dengan mekanisme yang ada, seperti yang diatur dalam Konstitusi itu sendiri. Seperti yang dijelaskan sebelumnya, dimana ini terlihat jelas dalam hukum positif di Indonesia yamg diatur dalam UUD 19454 dan UU No. 17 Tahun 2009, yaitu check and balances dalam bidang legislasi, anggaran, pengawasan.

Format politik Era Reformasi 1998 sampai sekarang merupakan format politik transisi. Oleh karena itu format politik era ini masih bersifat instabilitas atau tidak stabil. Namun dibalik instabilitas politik tersebut, terungkap adanya keinginan untuk lebih memberdayakan DPR. Pemberdayaan DPR yang dimaksud nyatanya diiringi

\footnotetext{
${ }^{17}$ Pasal 1 dan 2 UUD 1945 (setelah amandemen).

${ }^{18}$ Pasal 23F ayat (1) UUD 1945 (setelah amandemen).
} 
oleh pembatasan kekuasaan secara limitatif, akhirnya jadilah kekuasaan DPR yang menjadi tidak terkendali atau lebih bersifat parlementaris.

Atas dasar ini ditetapkan UU. Nomor 23 Tahun 2003 tentang mekanisme Pemilihan Presiden dan Wakil Presiden secara langsung, dengan maksud Presiden tidak terikat secara politik dengan DPR sehingga Prinsip Presidensil terus ditingkatkan. Walaupun dalam banyak hal, otoritas Presiden dalam hal tertentu bergeser ke DPR. Parlemen menjadi sangat kuat, dan bahkan seringkali masuk ke ranah kerja eksekutif. Sementara Presiden tidak punya hak veto. Tidak salah kalau dikatakan bahwa sistem pemerintahan memang presidensial tapi memberikan ruang bagi sistem parlementer. Berbeda dengan sistem parlementer, konteks koalisi dalam demokrasi presidensial bukanlah dalam rangka membentuk kabinet. Dalam sistem presidensial, pembentukan kabinet adalah otoritas presiden, walaupun di beberapa negara membutuhkan konfirmasi parlemen. Koalisi dalam konteks presidensial yang dikombinasikan sistem multipartai lebih diperlukan untuk mengefektifkan presidensialisme itu sendiri. Karena itu, persentase dukungan partai politik di parlemen adalah salah satu cara untuk mengokohkan sistem presidensial Indonesia. Dalam praktiknya, kekuasaan DPR yang terlalu kuat seakan-akan membuat Lembaga Eksekutif terkesan ragu dalam mengambil keputusan dan membuat mekanisme check and balances tidak berlansung dengan efektif.

\section{PENUTUP}

A. Sesungguhnya keberadaan sistem check and balances tersebut guna memperbaiki dan menata kembali pemerintahan yang baik (good government).

B. Pengaturan mekanisme check and balances antara Presiden dan DPR terdapat dalam berbagai bidang, yaitu legislasi, anggaran, pengawasan yang diuraikan sebagai berikut berbagai Pasal baik yang mengatur mengenai kekuasaan legislatif, maupun yang mengatur mengenai kekuasaan legislatif.

C. Kekuasaan Presiden dalam hal tertentu bergeser ke DPR.DPR menjadi sangat kuat, dan bahkan seringkali masuk ke ranah kerja eksekutif. Oleh karena itu, perwujudan daripada mekanisme check and balances sebenarnya sudah berjalan namun hanya saja tidak berjalan dengan baik, hal ini dikarenakan masih ada anggapan yaitu lembaga perwakilan rakyat dalam hal ini DPR terlihat bahwa 
dirinyalah yang lebih berkuasa sehingga cita-cita daripada check and balances tidak terwujud dan terlaksana dengan baik.

\section{DAFTAR PUSTAKA}

\section{Buku}

Asshidddiqie, Jimly, Hukum Tata Negara dan Pilar-Pilar Demokrasi, Konsistusi Press, Jakarta, 2006.

Jakarta, 2006.

, Pengantar Ilmu Hukum Tata Negara Jilid II, Konsistusi Press,

-----------------, Perkembangan dan Konsolidasi Lembaga Negara Pasca Reformasi, Konstitusi Press, Jakarta, 2006.

Atawa, I Gde Pantja dan Suprin Na'a, Memahami Ilmu Negara dan Teori Negara, PT Refika Aditama, Bandung, 2012.

Chaidir, Ellydar, Hukum dan Teori Konstitusi, Kreasi Total Media Yogyakarta, Yogyakarta, 2007.

Gaffar, Janedjri M, Demokrasi Kosntitutional Praktik Ketatanegaraan Indonesia Setelah Perubahan UUD 1945, Konstitusi Press, Jakarta, 2012.

Kansil, CST dan Christine S T Kansil, Latihan Ujian Hukum Tata Negara di Indonesia, Sinar Grafika, Jakarta, 2009.

Mahfud MD, Moh, Perdebatan Hukum Tata Negara Pascaamandemen Konstitusi, PT Raja Grafindo Persada, Jakarta, 2011.

Syafiie, Inu Kencana, Pengantar Ilmu Pemerintahan, PT Refika Aditama, Bandung, 2011.

Tutik, Ttitk Triwulan, Pokok-Pokok Hukum Tata Negara Indonesia Pascaamandemen UUD 1945, Cerdas Pustaka, Jakarta, 2008.

\section{Sumber Lain}

UUD Negara Republik Indonesia Tahun 1945 (setelah amandemen)

UU Republik Indonesia Nomor 27 Tahun 2009 Tentang MPR, DPR, DPD, dan DPRD Bahan Ajar Hukum Administrasi Negara, Fakultas Hukum Universitas Sam Ratulangi Manado 
Bahan Ajar Hukum Tata Negara, Fakultas Hukum Universitas Sam Ratulangi Manado

Bahan Ajar Praktek Peradialan Tata Usaha Negara, Fakultas Hukum Universitas Sam Ratulangi Manado

\section{Internet}

http://id.m.wikipedia.org/wiki/Sistem_Presidensial 